\title{
THE HISTORY OF LAPLAND AND THE CASE OF THE SAMI NOAIDI DRUM FIGURES REVERSED
}

\author{
Francis Joy
}

Abstract: The Sami are the indigenous peoples of northern Scandinavia and the Kola Peninsula in Russia.

Up until the periods between the 17 th and 18 th centuries the Sami practiced an indigenous form of shamanism, characterised by hunting and animal ceremonialism. After the crusade against the Sami and the practice of their ancient nature religion by the Swedish, Norwegian and Finnish priests and missionary workers, a subsequent number of Noaidi-Shaman drums were collected and in time exhibited in different museums throughout Europe, where many still remain today.

The Noaidi drums have been vital sources of information for scholars outside Sami culture, as well as the Sami themselves. In the 1670s, Johannes Schefferus, the German scholar and linguist wrote about the history of Lapland which was translated into Latin under the uniform title Lapponia. English, French and Dutch editions soon followed as did a German edition. This article discusses some of the implications for researchers due to a number of significant errors recently identified in these original manuscripts and furthermore, what this means for the Sami history, religion and culture today?

Key words: divination, errors, figures, illustrations, Lapland, priests, publications, reversed, Sami Noaidi

In the winter of 2002, I travelled to Finland to undertake studies in Circumpolar and sub-Arctic animism and shamanism, as an exchange student at the University of Helsinki, and a student of comparative religion. This was under the auspices of Juha Pentikäinen, professor of comparative religion, whom I had met in the fall of 2001 when he was visiting Bath Spa University in the UK, to present a series of lectures about Sami and Siberian shamanism, where I was a first year student, studying religious studies and European history.

Soon after the arrival in Helsinki, an invitation arrived concerning a conference on Finno-Ugric Shamanism about the minority peoples of Siberia. The title of this event was From Taiga to Tundra, and was to be held at the Museum of Cultures in Helsinki, organised by Institute for Cultural Research, Department of Finno-Ugric Studies in University of Helsinki, and the M. A 
Castren Society, chaired by Professor Pentikäinen and the President of the Society for Shamanic Research in Hungary, Mihály Hoppál. Both scholars were amongst a host of others, to present a series of lectures about the Sami and Siberian peoples and their respective cultures and religious practices.

As part of the conference, there were a large number of historical and cultural artefacts on display at the museum, which included shaman drums, costumes and garments, ritual and ceremonial items, hunting weapons and a series of wooden animal figures and deities. These had all at one time served as the religious implements of the Nenets, Khanty, Mansi, Selkup and Sami, the native peoples of the northern areas of the globe. The extensive display was titled The Siberian Collection.

Documented on one of a number of information sheets given to the audience, was a brief introduction to two Sami Noaidi/Shaman ${ }^{1}$ drums which had originated from the Kemi Lappmark area, in present day northern Finland. The larger of the two drums measured approximately $83 \mathrm{~cm}$ in height, which seemed like a master-piece in itself, and was currently the property of the National Museum of Antiquities in Stockholm.

In April of the same year (2002), the opportunity to take a trip to the far northern areas of Scandinavia to visit several of the museums in Lapland begun on an overnight train to Rovaniemi, the capital of Finnish Lapland. After a visit to the Arctic Centre in Rovaniemi, to see what could be learned about the Sami, indigenous people of the north, through a fine and colourful series of exhibitions. To follow this, a further journey commenced across the border in to Norwegian Lapland to the Sami Museum (Sámiid Vuorká-Dávvirat) in Karasjok. The first initial encounter with the old noaidi drums in the museum was with a plastic replica of one collected at the times the noaidi of Lapland were persecuted during the 17 th century witch hunts conducted by the Swedish church; it was hanging suspended from the roof on several ropes.

After asking a few questions to a female member of staff about the drum, she told me in no uncertain terms that both the Norwegian and the Finnish Sami did not have any of their own drums in their respective museums, and that there were several Norwegian Sami drums in the United Kingdom in the British Museum and in Cambridge University Museum.

It was during the investigation into the plight of the Norwegian drums in the UK, via a visit to the Siida Museum in Inari, Finnish Lapland that a second encounter with another drum took place, namely, with the larger of the two Sami noaidi drums from Kemi Lappmark, which was on loan from Sweden, and on exhibition there. Whilst at the Siida museum, the chance to take a couple of photographs of the drum would serve as an important factor for what was to unfold. 
Once back in Helsinki, I made some comparisons between the black and white copy of the drum which was in the first English publication of Lapponia from 1674, and the newly coloured photograph taken at the Siida Museum. On close observation it became obvious that the portrait of the drum from the black and white copy and the coloured one were somehow different, but it was not initially clear why.

After the initial observation of these differences and a careful study of both the images of the drums and the layout of the painted figures on the surfaces of the drums, it became evident that the images were reversed when compared with each other. Initially, what had happened, as to how or when this had happened and to what extent these differences varied in the literature that had been published almost 340 years previously was not understood and therefore, this needed to be investigated further. What was to unfold is the purpose for writing this article.

\section{INTRODUCTION}

This article investigates the plight of the two known Sami Noaidi drums that have originated in Kemi Lappmark ${ }^{2}$ (Manker 1938: 685) in present northern Finland. The larger of the two is currently the property of the National Museum in Sweden, and the second, a slightly smaller drum is owned by the Städtisches Museum für Völkerkunde, Leipzig, Germany³ (Manker 1938: 686) and can be seen on display there.

The preliminary aim of this article is in this first instance, to give the reader a brief introduction to the subject under discussion of both the origins and the history of the drums in question. This is followed by an examination of the sources and material of which there are chiefly four different publications, including documentation of the drums case histories, originating in Sweden during the latter half of the seventeenth century. These sources by and large pertain to the events which took place as the Swedish crown asserted its colonial powers through Christianity over the indigenous peoples of the northern areas of Lapland, thus bringing about religious change. At the time, there were a number of priests who figured prominently as informants for the church, and who were predominantly responsible for the religious change amongst the Sami; their tasks were centred on the collection of data about the drums and the activities associated with their usage. This information and motivations by the priests have played a key role in the publication of a series of books about Lapland life and customs titled in English The History of Lapland, which are the texts under investigation here. 
The second aim is to assess the literature that has been written about the drums both historically and more recently and to clarify the problems encountered in this task. The motivation for the enquiry focuses primarily on the positioning of painted zones and sun centred systems (and non noaidi drum diviners used $)^{4}$, in relation to the different publications, which the noaidi used traditionally to divide the content on the drums into three different levels, as a way of structuring their animistic world view. The relevance and indeed importance of the zones for understanding and interpreting the different elements in Sami culture and religion, has by and large been one of the most debated subjects amongst scholars since Ernst Manker produced his esteemed works. His Die lappische Zaubertrommel. Eine ethnologische Monographie 1, from 1938, which is an in-depth study of all the Sami drums currently preserved in various museums around Europe. Following this, a second edition from 1950 is titled Die Lappische Zaubertrommel. Eine ethnologische Monographie 2. It is published with different content which pertains to analysis and interpretation of the symbolism that can be seen pictured on the surface of the drums.

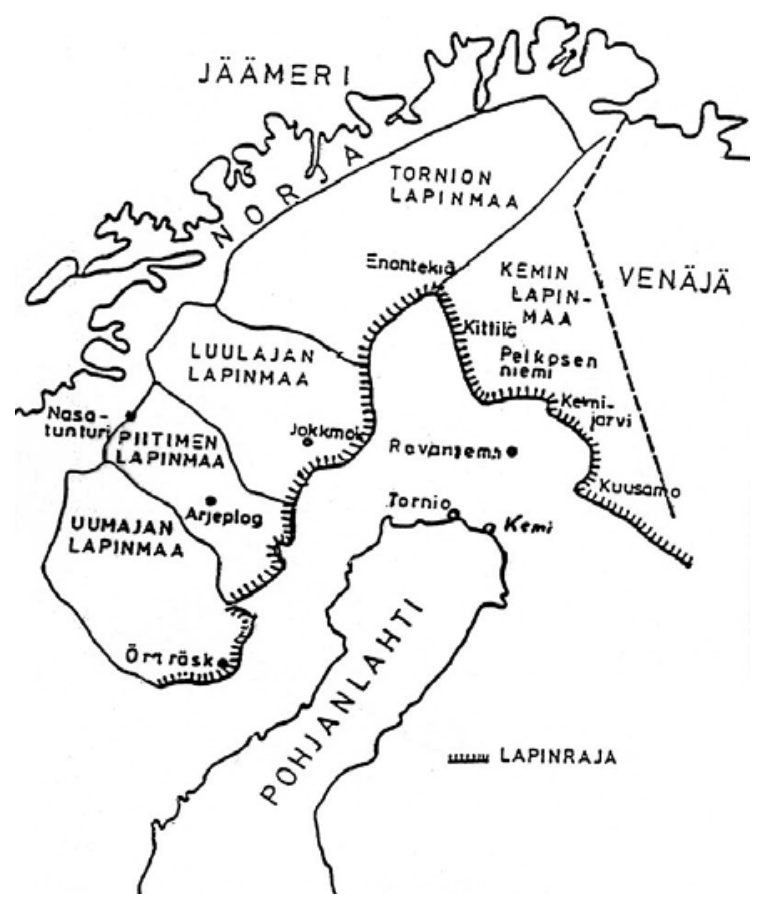

Figure 1. An old map of Scandinavia showing the division of the northern parts of the Swedish Empire into the five Lappmarks. The map also shows the Lapland border: Lapinraja. Received with grateful assistance from Risto Pulkkinen. 
Both of Manker's editions include analysis and discussion of the two drums from Kemi Lappmark and their individual history in addition to different typologies, and origins and description of 75 other drums, making a total of 77 drums (Itkonen 1943-1944: 68). Manker's second publication discusses, in addition, the positioning of painted human, animal and divine figures, trying to illustrate how the Sami world-view was presented and how it varied considerably, firstly by region and area; and secondly, according to the noaidi's experience and interaction with the spirits in these zones and the way in which this was then documented on the drum which served as a kind of Cosmological Map prior to and during hunting.

These early sources have been used extensively in the study of comparative religion, folklore and ethnography since their publication; it is only recently, that after analysing them, a number of historical problems became apparent concerning the positioning of the figures on the drums. These were in the early "foreign" publications, and therefore, the discussion which is to follow seeks to clarify and understand what the implications are for scholars of comparative religion and folklore who aim to study Sami religion and how this, in turn, impacts on cultural history and religion.

\section{THE DRUMS AND THEIR HISTORY}

The remaining 71 (Itkonen 1943-1944: 68) Sami noaidi drums have been preserved throughout Europe in various museums in Italy, Sweden, France, Germany, Denmark, Norway, and Great Britain (see also Manker 1938). They were collected from the northern areas of present Norway, Sweden, Finland and Russia, initially by "missionaries and explorers in the 17th and 18th centuries and sold and shipped to private [collectors] all over continental Europe" (Pentikäinen 1998: 27). It would seem that as interest in the drums as religious artefacts, as well as the priests' accounts of their usage in rituals dedicated, to the arts of divination and prophecy became more widespread, the drums gradually "found their way to the museums" (Pentikäinen 1998: 27).

At the beginning of the seventeenth century, Sweden as a kingdom was in the process of seeking to expand its territories throughout the northern parts of Scandinavia and up into the far reaches of the northern areas of Norway and Finland. The drive into Lapland by the Swedish Empire brought news to the towns and cities further South of "evil rumours about the inhabitants in the far north, [which] cast shadows of a barbarous paganism on protestant Sweden (and it might be added) whose, astonishing victories on the German battle- 


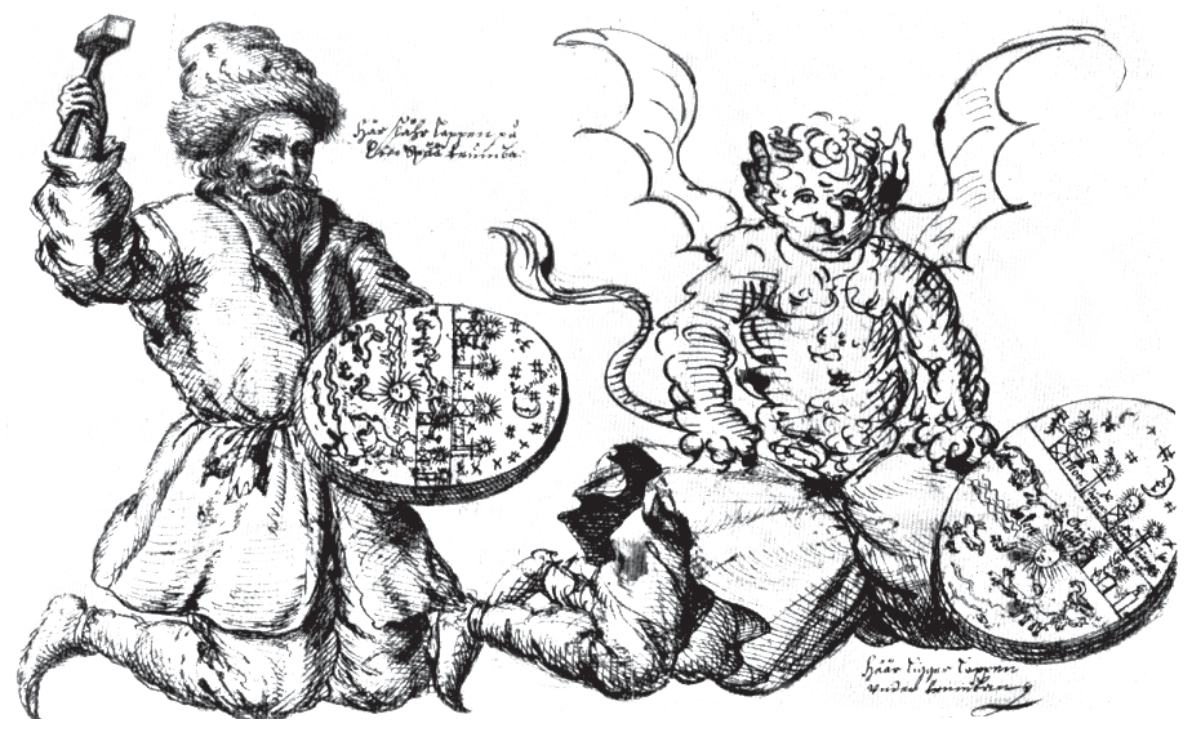

Figure 2. This is Rheen's illustration that he sent to Schefferus, depicting a Sami noaidi moving through different stages of consciousness into a trance state where he depicted initially on the left side of the picture "preparing himself for the trance by beating the drum with his hammer, on the right he is lying in a trance whilst his soul, aided by the alter ego" (Pentikäinen 1998: 39), or guardian spirit, as the noaidi begins his journey into the world of spirits. This illustration is taken from Ernst Mankers: Die lappische Zaubertrommel. Eine ethnologische Monographie (1938).

fields were said to be due to the witchcraft of Lappish sorcerers in the armies of Gustavus Adolphus.” (Ahlström 1971: XI)

Also, and at the same time, "the Swedish state had performed a blessed and noble deed by introducing the gospel and enlightenment in otherwise godforsaken tracts [into its culture]. But the distances were vast, the churches few. Pagan evil still had plenty of room at its disposal. In other words, the devil was at large in Lapland." (Ahlström 1971: XI)

Therefore, and with much conviction, the confrontation of the nature religion of the Sami in the far north by Christianity assured that clergymen and missionaries alike frowned upon the Sami arts of using the magical drum for prophecy, fortunetelling, and divination. These were activities related primarily to sacrificial ceremonies concerning the successful breeding and hunting of animals, and successful outcomes in business and life affairs via the use of magic, these were interpreted by the church fathers as solely "devilish practices" (Schefferus 1674: 54).

In 1670, the High Chancellor of Sweden, Magnus de la Gardie appointed German linguist Johannes Schefferus to investigate claims of sorcery and witchcraft amongst the Sami in the northern areas of Sweden, Norway and Finland. 
The undertaking was seen at the time, merely as an attempt to clarify the rumours of such practices that had earlier been provided by priests and missionary workers who sought to convert the Sami to Christianity. The outcome of Schefferus's investigation concluded that there was no basis for this so called witch hysteria in the north.

As Schefferus had never been to Lapland himself, information was sent to him at Uppsala from "the priests of the northern districts [who] wrote down accounts of the Lapps in their parishes. These reports were then forwarded to Schefferus for editorial rewrites." (Lundström 2002: 1)

The names of the priests whose manuscripts were sent to Schefferus, and which contained information about the Sami communities in the northern areas, were namely Samuel Rheen, Olaus Graan, Nicolaus Lundius and Johannes Torneus; and from Kemi Lapland Gabriel Tunderus. It is helpful at this point to make it clear to the reader that among these informants there were chiefly three priests whose contributions were considered important by Schefferus. The first is by the Swedish clergymen Samuel Rheen.

“Rheen's description concerns mainly the Lule Sami. He provides information about their customs and their pre-Christian cosmology. The report included pictures of a shaman's drum and a shaman falling into trance. Rheen's report (En kortt relation om lapparnes lefwarne och sedher, wijd-Skieppellser, sampt i många stycken grofwe wildfarelser (A short account of the Lapps' life and customs) was the first of the sources for (Schefferus's work) to be submitted about 1670." (Pulkkinen et al. 2005: 337)

Reports that were sent to Schefferus by other priests from the northern districts are considered problematic as far as authentic source material goes. This is because during Rheen's assessment of Sami culture and customs, the material he formulated and sent to the "Swedish College of Antiquities (which had by all accounts) requested clergymen working in Lapland to supply information (to) Schefferus, (had been) circulated among the other clergymen in Lapland, with the result that many who subsequently contributed source material (to Schefferus) based their accounts to a considerable extent on Rheen's report." (Pulkkinen et al. 2005: 337)

In addition to Samuel Rheen's reports, another priest whose past work was criticised after examination by Schefferus was Magnus Gothus Olaus (14901557). Olaus Magnus was the author of one of the earliest accounts of the preChristian religion of the Sami, included in his major work History of the Northern Peoples (Pulkkinen et al. 2005: 251). 
"Magnus Gothus Olaus was Swedish priest, Archbishop of Sweden (and) ethnographer (whose work according to what has been written) contains a fair amount of fanciful material. His description of a shaman falling into a trance was almost certainly not based on something he had personally witnessed. It follows the pattern of Saami legends. He (also) talks about Finnish seers and witches. In his (collaboration with the Swedish priests) Johannes Schefferus puts right many of the misrepresentations of Olaus Magnus, and in fact his work was to a great extent written in order to correct many of the rumours regarding the sorcery of the (Sami) arising out of the descriptions of Olaus Magnus." (Pulkkinen et al. 2005: 252)

The third informant, who could be considered as one of the most important with reference to the Finnish drums originating from the Kemi Lappmark area is Gabriel Tunderus, "a Finnish clergyman working in Lapland who converted the Kemi Saami to Christianity. As a result of Tunderus' missionary work, the Kemi Saami renounced practices connected with their ethnic cosmology, including the use of the shaman's drum." (Pulkkinen et al. 2005: 418)

By all accounts, the information which was sent to Schefferus by Tunderus was written at the time as manuscripts. These manuscripts were later published in a serial publication about Swedish language and ethnology. The title of the article is En Kort Underrättelse Om The Österbothniske Lappar: som under Kiemi Gebiet lyda. This was published in Swedish in 1905 in de svenska landsmålen och svenskt folkliv XVII: 6, in Uppsala ${ }^{5}$ (it was later published again in Svenska landsmål ock svenskt folkliv, 1910). Other manuscripts produced by Tunderus describe the Kemi Lapp bear hunting rituals which were intricately woven into the Lappish pre-Christian religion ${ }^{6}$.

\section{THE MATERIAL OF THE STUDY}

Schefferus's task of collecting and editing the material presented by the Swedish priests produced a detailed and thorough assessment of Sami culture and beliefs which was finally published in 1673 in Latin under the uniform title Joannis Schefferi Argentoratensis Lapponia (see Schefferus 1673); it included an inspiring and probably one of the most important chapters (number 11), with reference to the art of the noaidi and the history of six particular noaidi drums, titled Of the magical ceremonies of the Laplanders (Schefferus 1674: 50 ). At the beginning of chapter 11 , the pages contain illustrations of the six 
Sami drums, including the two Kemi Lappmark ones and the hand held instruments-hammers, used to play them with, which are the purpose of this study.

The rumours in Europe that the Sami noaidi were an essential part of the victorious Swedish army appear to have been instrumental as well as a very important motivation for the publication of Lapponia, first printed "in the basic Latin version in Frankfurt am Main titled Joannis Schefferi Argentoratensis Lapponia in 1673, and then introduced to English readers in 1674" (Ahlström 1971: XI-2), titled The History of Lapland wherein are shewed the original manners, habits, marriages, conjurations, \&c. of that People. Written by John Scheffer, Professor of Law and Rhetoric at Upsal in Sweden, at the Theatre in Oxford, MDCLXXIV (1674), in a 147 page volume. The book was "to be sold by George West and Amos Curtein". In addition, "a young English student by the name of Acton Cremer did the translation from Latin to English" (see Lundström 2002) ${ }^{7}$. This edition was later republished in 1971 in Stockholm with the same illustrations.

There are two further publications from the Latin edition that have been translated into English, the second from 1704 that contains illustrations of the six drums, and being of the same title The History of Lapland. This edition was printed for Tho. Newborough, at the Golden-Ball in St. Paul's Church-Yard, by R. Parker under the Royal-Exchange.

The third, a smaller edition is titled The History of Lapland, printed for R. Griffith, in London, 1751. This edition has no drum illustrations in its content at all.

Other publications of Lapponia include a translation into German titled Joannis Schefferi von Strassburg Lappland. The German edition was printed at the publishing house Martin Hallerborden/Buchhandlern, in Frankfurt am Main und Leipzig, in 1675.

The French translation Histoire de la Laponie, was published in Paris at Chez la Veuve by Olivier de Varennes (chez la veuve Olivier de Varennes - by the widow Olivier de Varannes), au Palais, dans la sale royale, au vare d'or, in 1678. The edition was translated by Augustin Lubin (see Schefferus 1678).

The Dutch translation was published in Amsterdam in the year1682, titled Waarachtige en aen-merkens-waardige Historie van Lapland, by Jan ten Hoorn, Boeckverkooper, Over't Oude Heeren Logement. It is not clear who the translator was for this edition (see Schefferus 1682). ${ }^{8}$

The extensive research and study of material undertaken by Schefferus and notably that which is concerned with the Sami drums is far from conclusive and according to the foreword written by Gunnar Ahlström in the second printing of the English edition published in Sweden in 1971: 
"Schefferus went to work making himself familiar with what was written before on the subject, he had access to more authentic field material. Local officials in the North, clergymen, bailiffs, and other reliable informants were requested to send him reports and observations. He never went up to the latitudes himself but he saw fur-clad little people at the winter markets in Uppsala." (Ahlström 1971: XI)

It is important to take into account this because it helps to establish how Schefferus was influenced by what could be described as a lack of knowledge about Sami culture and customs as well as field-work experience. Having said this, Schefferus can be merited on the pictures of ritual objects and artefacts, received from his various sources, that have been used for publication in the Latin and German editions. At the same time, the illustrations seen on pages 51 and 52 in the first English edition from 1674, which described the only two known Kemi Lappmark Sami noaidi drums, and the other two English editions published in 1704 and the republished edition from 1971, as well as the French and Dutch editions, need to be discussed in greater detail with reference to publication to clarify errors that were made in these earlier editions.

Both Swedish (Schefferus 1956) and Finnish (Schefferus 1963) publications have illustrations of the drums in them which are taken from the original Latin edition and are correct illustrations of all the drums.

\section{THE DRUMS ILLUSTRATIONS AND THE PROBLEM OF INTERPRETATION}

The questions raised in this study are primarily concerned with the importance of the structure of the zones on the drums and designation and positioning of each of the figures and smaller structures within these areas such as animals, deities, human figures and sacrificial areas, that have been recognised as giving valuable insights for helping us to understand to some degree the nature of the content and territory depicted on the surface of each drum by the noaidi, as having both depth and value for study purposes.

The first two illustrations have been taken from the original Latin publication of 1673 (microfilm), of the two Finnish drums E \& F from Kemi Lappmark which are exhibited below. In addition, and to try and avoid confusion, Ernst Manker in his assessment has used numbers to category the drums. There are numbers 43 (drum E) and 44 (drum F). Several other illustrations which are similar are not of very good quality in their appearance, this is because of the quality of the printing and publication at the time. ${ }^{9}$ 


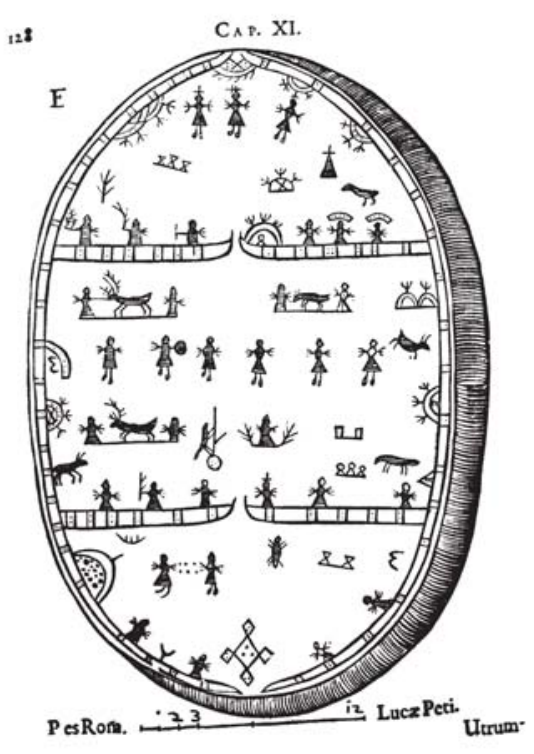

Figure 3.

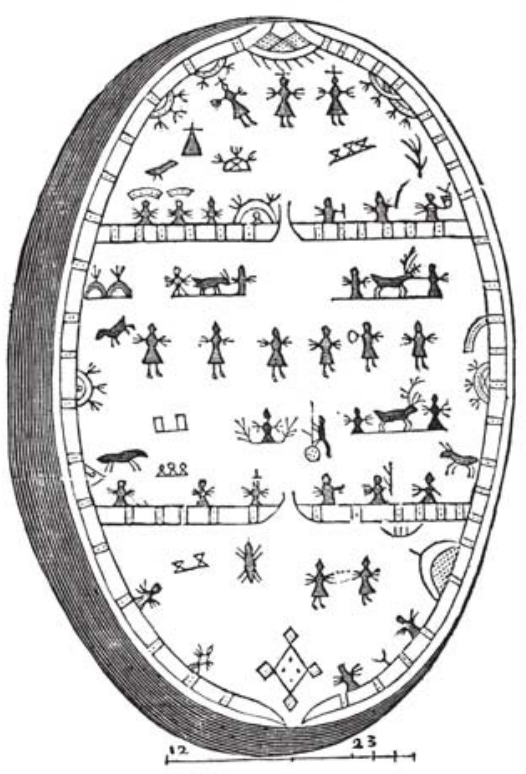

Figure 5.

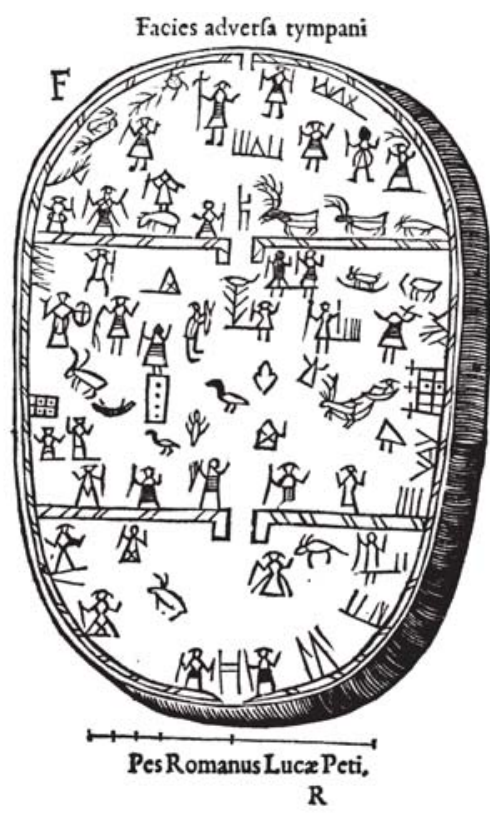

Figure 4.

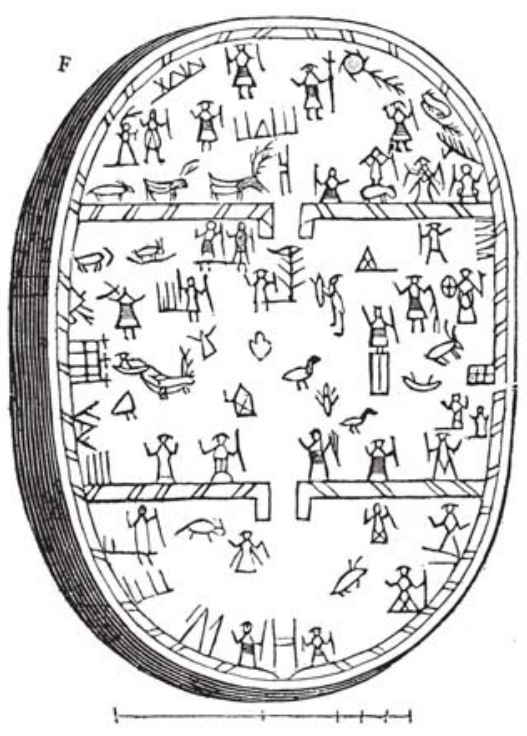

Figure 6.

Figure 3. Drum $\boldsymbol{E}$ from Kemi Lappmark. The illustration of drum $E$ shows the profile of the side and bottom of the drum as being to the right hand side in the picture. The overall portrait of the drum shows its contents divided into three levels or layers. In this picture, in the top zone on the left, there are three figures that are visible and are numbered by T. I. Itkonen as numbers 1-2-3. The figure in the middle 
appears to be holding a forked object which is pointing upwards in its left hand. In the middle zone on the left hand side, can be seen two antlered reindeer figures facing west, to the left, and in the bottom zone on the left, there are two figures, numbered 5 6 by Itkonen, who have dots between them. The size of drum $E$ is recorded to be "85 $x$ 53 x $11.5 \mathrm{~cm}$ " (Itkonen 1943-1944: 69).

Figure 4. Drum F from Kemi Lappmark. The illustration of drum E, also shows the sideledge profile of the drum as being on the right hand side, the lines are running horizontally and not vertically. Like drum $E$, drum $F$ is also divided into three zones or levels. In the top zone to the right hand side, there are three animals, two which have antlers, who are facing towards the left, west. In the middle zone on the left side, there are several figures standing close to each other. The figure of the far left is holding a circular object which has a cross in the middle of it indicating what could be a drum in one hand and a hammer used to play the drum in the other hand. In the lower zone at the far left side there are two figures that look as if they are wearing hats which are hanging from their heads. Finnish scholar Itkonen has recorded the size of drum $F$ as being "66 $x 42.5 \times 10 \mathrm{~cm}$ " (Itkonen 1943-1944: 71).

Figure 5. Drum E from Kemi Lappmark. The sideledge profile of the drum is pictured on the left hand side in this illustration taken from the republication of the original English copy first published in 1674, and shows what looks like the grain of the wood. The same figures seen on the drums from the original Latin edition can be found facing in the opposite direction. For example, the figure in the top zone that is holding what looks like a forked branch is now on the right side. The reindeer figures in the middle zone that were on the left facing west are now on the right facing east. The two figures in the bottom zone, that have what look like dots between them are now on the right side.

Figure 6. Drum F from Kemi Lappmark. The sideledge profile of the drum is on the left side and is opposite to the profile on the Latin drum, and also indicates a kind of grain in the wood. The three animal figures, two which can be identified as reindeers, standing on the top zone are found on the left side facing right, and east, as opposed to the same ones on the Latin publication, that are on the right side facing west. The lines that can be seen on the drums from the 1674 English translation run vertically and not horizontally as is the case in the original Latin publication.

Figure 7. Drum $\boldsymbol{E}$ from Kemi Lappmark. Taken from the French publication of 1678 (microfilm). The lines which are much finer in detail are running vertically in the same fashion as the illustrations in the Latin publication. The figures are also reversed by comparison with the original Latin edition and again this is seen through the two reindeer figures positioned in the middle zone on the right facing towards the east.

Figure 8. Drum F from Kemi Lappmark. Taken from the French publication 1678 (microfilm). The lines here also run vertically and the sideledge profile of the drum is to the left; the figures are also reversed when compared with the illustrations in the Latin publication

Figure 9. Drum E from Kemi Lappmark. This is the illustration from The History of Lapland second English publication, dated 1704. The right side is slightly distorted in the microfilm image, because it has been printed against the fold in the book. The figures on both the right and left sides of the drum are reversed in comparison to the original Latin publication.

Figure 10. Drum F from Kemi Lappmark. This is the illustration from The History of Lapland second English publication, dated 1704.The illustrations of figures on the right and left sides are reversed when compared with the illustrations seen in the original Latin publication. 


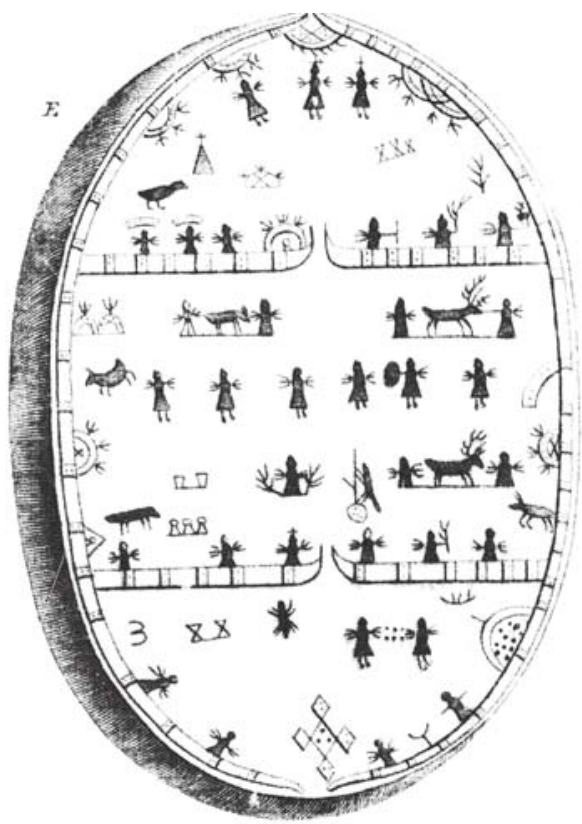

Figure 7.

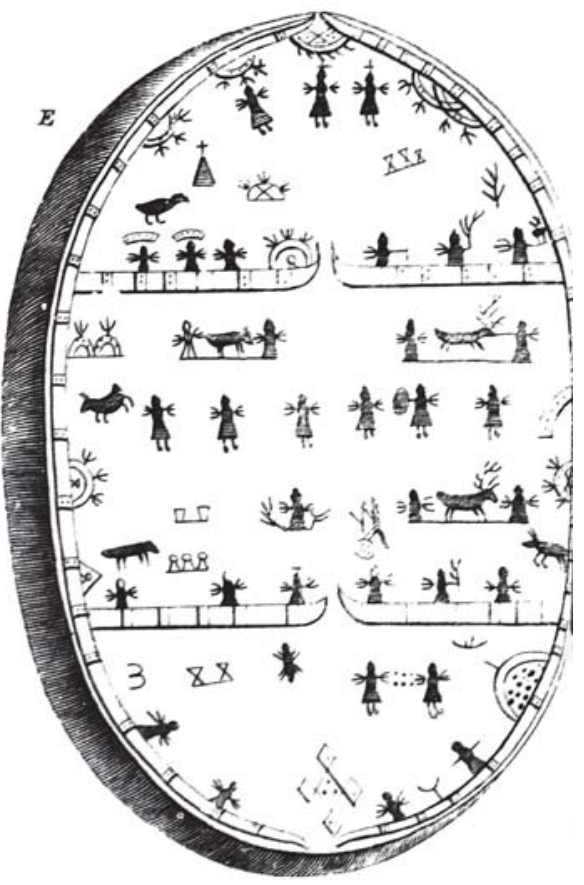

Figure 9.

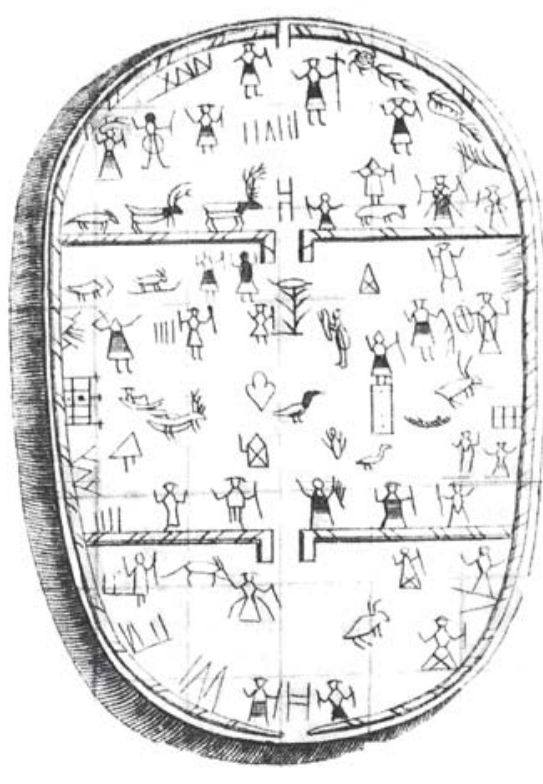

Figure 8.

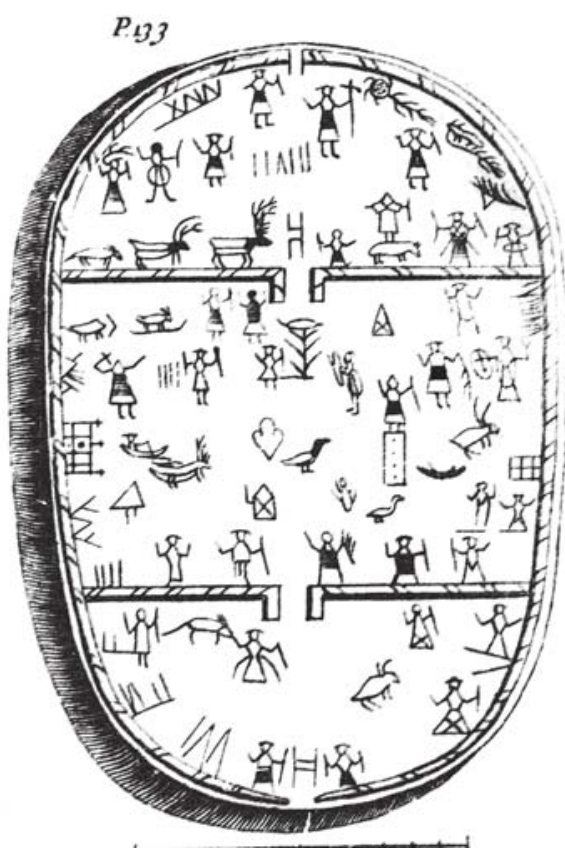

Figure 10. 
In Manker's inventory of the drums, Die lappische Zaubertrommel. Eine ethnologische Monographie 1938, drum F is documented to have been received by Schefferus from "Henrici Flemming who was an officer in the Finnish cavalry" (Manker 1938: 32) ${ }^{10}$. Drum E on the other hand, was received by Schefferus from Magnus Gabriel de la Gardie, "the Chancellor of the Kingdom" of Sweden (Schefferus 1674: 49).

The two drums pictured next are the same drums from Kemi Lappmark but the illustrations used here are taken from the first English publication from 1674, (which was reprinted in 1971). The illustrations in the English edition were taken from the original Latin one ${ }^{11}$.

There appear to be two main reasons why these illustrations vary as they do, and may to a greater extent at this present time be unrecognised simply because the variations happened three hundred and forty years ago. Therefore, the task ahead is to examine and then present to the reader how extensive the mistakes/variation run?

Swedish scholar Lillemor Lundström points out that in the first English edition which was re-published in Sweden in 1971, "the illustrations in the book consist of 25 woodcuts made in compliance with the author's own drawings" (Lundström 2002: 1). The woodcuts, as I understand it, are where the figures are carved to make them stand out for printing purposes, and the pictures are printed with the text.

Lundström does make a distinction between the Latin and English publications by clarifying that

"the English edition is the first translation of Lapponia, originally published in Latin and printed in Frankfurt am Main 1673. The text of the translation is partially curtailed but does contain all the illustrations belonging to the original (though in a slightly different style and often reversed), and the author was never able to read his text in proof, as the original edition was published in Germany, and therefore has a number of misprints." (Lundström 2009) ${ }^{\mathbf{1 2}}$

One may consider during the times the literature was published, the printers and publishers themselves were not as interested in the subject as the academics were, and therefore, mistakes were bound to happen.

Further enquiry into other publications of Lapponia revealed that illustrations of the two Kemi Lappmark Sami drums pictured in the French edition published in 1678, have been printed on pages where there is no text at all, and the mistakes that are obvious in their illustrations appear to be due to the fact that both the drums and the figures which are pictured in this edition are portrayed the same way as is seen in the English edition, everything is re- 
versed because of the way the illustrations in the book have been printed. However, and in addition to this, the side/edge profile of both drums in the French edition are not illustrated in the same way as the English drums where the lines are running horizontally; the lines in the French edition run vertically, the same way as the lines seen in the Latin publication, but the side profiles of the drums are positioned on the left side, as seen on the English publication. Therefore, it may be assumed here the illustrations used in the French publication were taken from the English one, but it is not clear how the side/edge profiles were made as they were.

I consulted Sirkka Havu from the National Library of Finland, who specialises in rare books, and was to discover that apart from using woodcuts, some publishers also used copper plates for printing purposes, onto which images were engraved without text. This could be the case with the illustrations from the French edition and it may indicate the answer to the question concerning the same illustrations being used/copied from the English publication for the French one, thus in preparation for publishing by Oliver de Varennes in Paris, the edges of the drums were engraved. However, what happened in between is a mystery.

Investigation into the publication of the French edition of Lapponia in Paris in 1678 revealed some interesting points concerning whether or not the same illustrations were taken from the English 1674 edition. The first point is according to the preface in the book, Olivier de Varannes, the publisher, was given a manuscript of Lapponia, but there is no mention who or where it came from. Furthermore, the King of France at the time Louis XIV made strict copyright laws declaring that there were to be no other publications made from the original for a period of ten years, and if any person was found to have produced a copy of the book unlawfully, the penalty was a 3,000 livre-pounds fine and confiscation of all material related to the book ${ }^{13}$, which suggests the book was of great importance to the French at the time because Sweden had close political and military ties with France.

It is also worth noting that the second English translation, dated 1704, has copies of the drums which have been engraved on copper plates before printing. In the preface of the book the publisher states the following: "this translation we now present to the world, is done from the last edition in the original Latin, and collated with a French translation printed in Paris, which contains several addenda that the translator had from the author, all of which are here taken in. The copper cuts we here make use of were done in France by Monsieur Bols." (Schefferus 1704: Introduction) Therefore, the prints of the drums in this edition are the same as those in the French edition, which states the obvious, the illustrations in the 1704 edition are also reversed. 


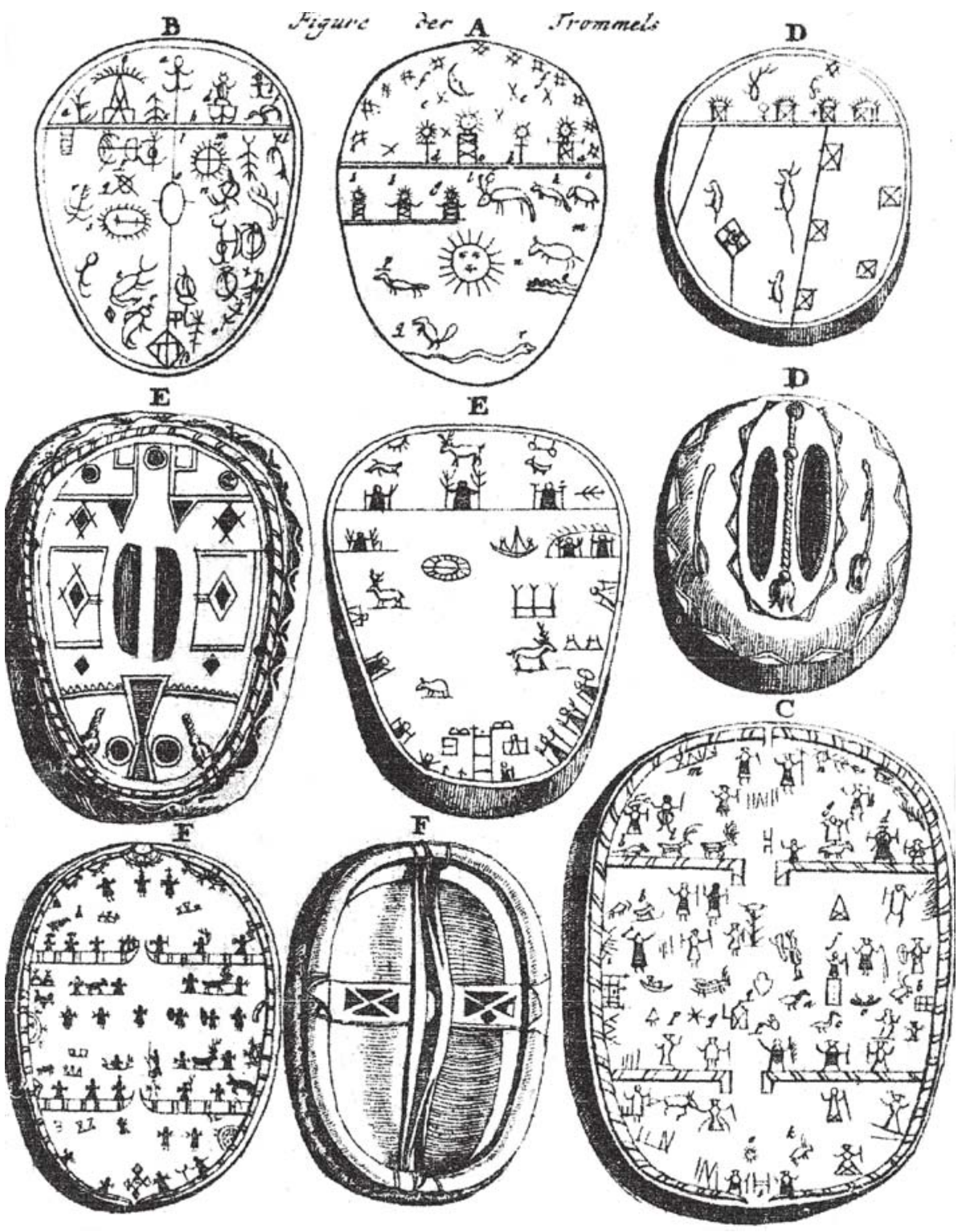

Figure 11. Taken from the Dutch publication of 1682, which is on microfilm. These illustrations show both front and rear designs of the drums labelled: $E$ and D. By contrast to what is presented above, the drum which is labelled E, is shown in all other publications as drum C. Also, there appears to be some confusion concerning the Kemi Lappmark Sami drum on the far right at the bottom concerning a mix up of the letters used to identify the Kemi Lappmark drums. The rear of the drum in the centre on the bottom line is marked under the letter $F$ which is correct. However, its size is the same as drum E which is to the left, but in Manker's inventory of the same drums, the design of the drum corresponds with the rear of drum $F$ which is labelled as drum $C$. In this case in the Dutch publication drum $F$ which is marked $C$ is much larger? 
The Dutch edition of Schefferus's Lapponia published in 1682 has within its pages illustrations of 6 Sami noaidi drums on an engraved plate. The three drums at the bottom of the plate can be identified as the Sami drums from the Kemi Lappmark area, the ones on the far left and right are facing outward, the middle one is pictured from the rear. The drums are recognisable as the Kemi Lappmark ones because the illustrations are reversed as seen in the English publication, therefore, indicating that all the illustrations may have been taken from the English or French publications. The lines on the edges of the drums also run vertically and are positioned on the left side.

The mistakes that have become evident concerning the two drums from the present Finnish Lapland area are also apparent with four other drums also illustrated in the same chapter in Schefferus's History of Lapland. These four other drums are labelled A, B, C and D; and are all pictured in Schefferus's first Latin publication Joannis Schefferi Argentoratensis Lapponia, in their true portraits. In the first English publication of 1674, the 1704 second edition as well as the republished edition, and the French and Dutch editions, the drums and their contents are presented in reversed order as well.

I have provided illustrations of the four other drums from Schefferus's publication, thus highlighting the mistakes. The drums A \& B from original Latin edition of 1673 are presented first so the reader can, on careful examination, see the true positioning of the drums and the illustrations of the figures. The landscape in drum A shows several important features to it which need to be recognised for study purposes. In the top zone or area of the drum there are four figures, and a picture of the crescent moon which is slightly to the left side. Below, is a kind of platform on which three figures are standing, this is situated on the right hand side of the drum. Underneath this is a sun figure in the centre of the drum.

A further point in need of clarification concerns drum A pictured in Schefferus's Latin edition, where it is pictured with three other drums, whereas in Ernst Manker's publication (Die lappische Zaubertrommel eine ethnologische Monographie), the drum is also being played by a Sami noaidi, who is accompanied by the devil like figure. The picture is the one sent to Schefferus by the clergyman Samuel Rheen, and the one used in the illustration on page 4 above. The location of the origins of the drum A, is Lule Lappmark according to Manker (1938: 393) which is in Swedish Lapland. There is mention of the drum in Manker's book in the chapter Nicht erhaltene Trommeln, not existing drums.

The landscape in drum B shows an area at the top of the drum where to the left there is an elevated figure with raised arms and what look like horns on its head. Below on both the right and left sides of the larger area of the drum are 


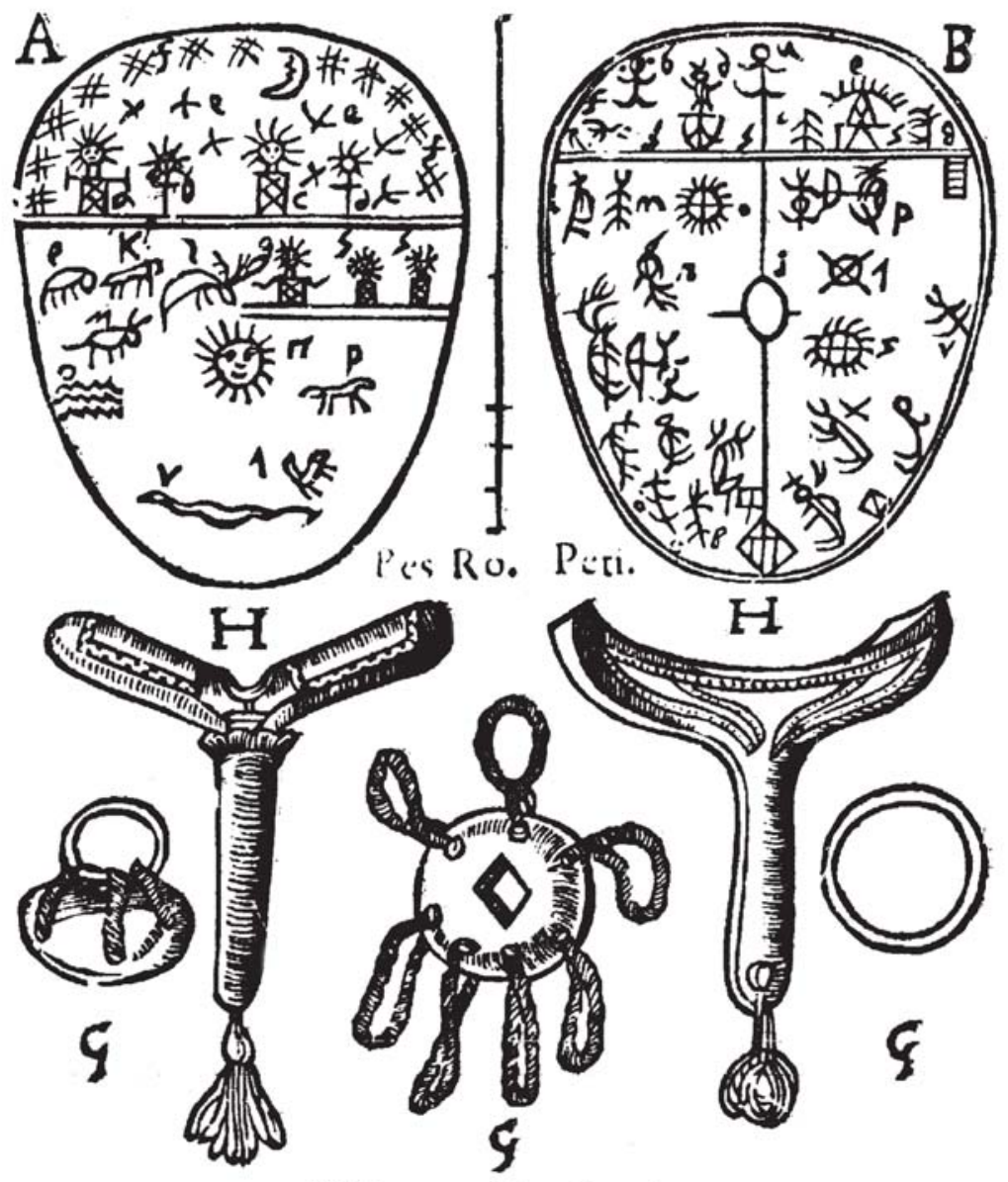

\section{Notarum Explicatio.}

In Tymparo A. a. Thor. b. famulus ejus. c. Stcoorjunkare. d. famuius ejus. e. aves. $f$. Itellix. g. Cliriffus. h. A poftoli cius. 2. urlus. k. Lupus. l. rangifer. m. bos. n. iol. o. lacus. p. vulpes. q. ficiurus. r. ferpens. hammers the Sami noaidi and more general drum diviners used as instruments to strike them with, as well as the copper rings which acted as a guide during divination. Also, the names of the figures on the drums in Latin. 


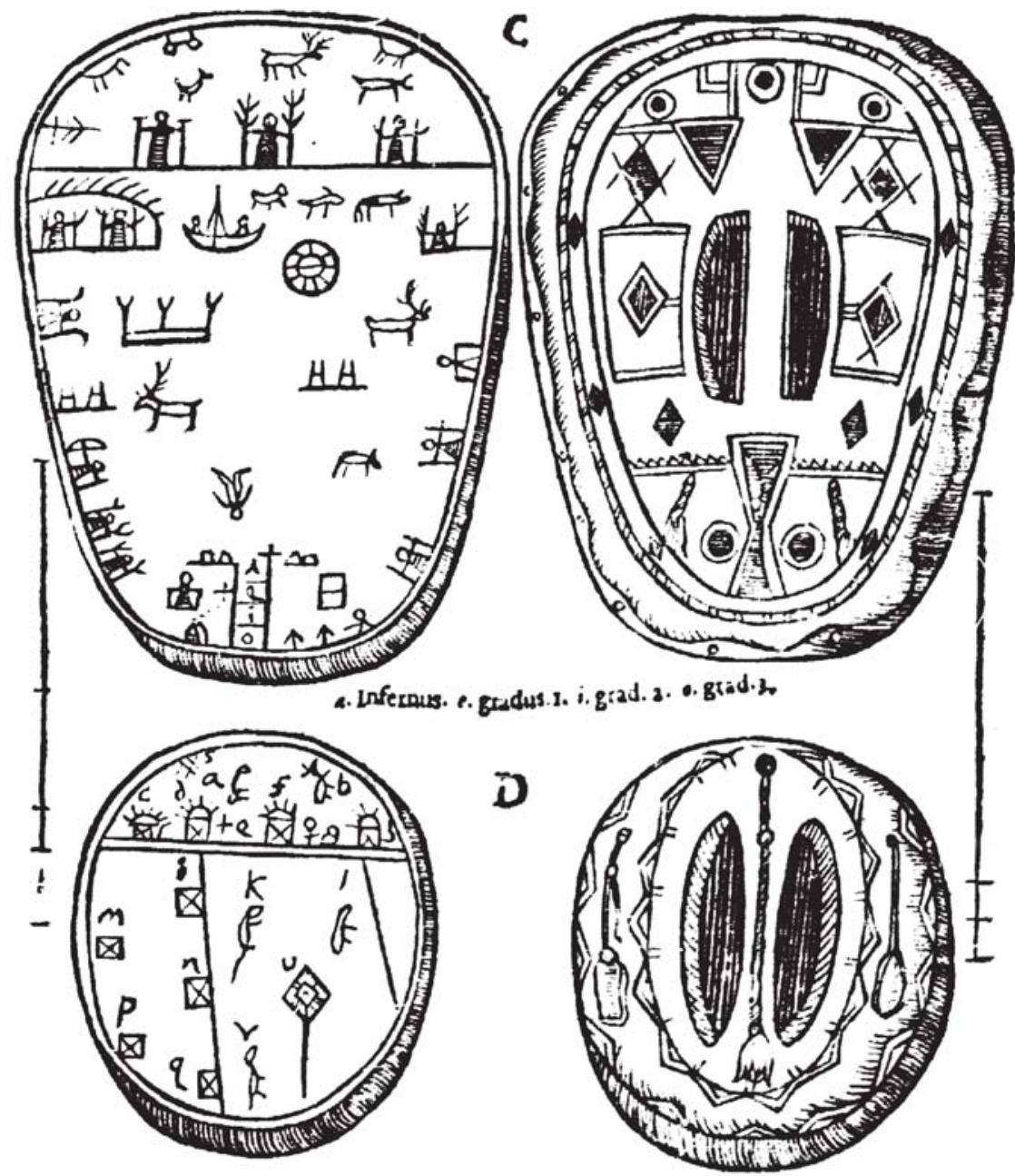

4. notnt aves. b. vulpes nigras. c. Tiuur, deum. d. Thoor, deum. e. mallcun $T$ horonis. $f$. Stoorjunkare, $g$. idolun ligneum $h$. ta mulum. i. ftellam. $k$. bovem. l. hircum. m. ftcllanı. n. lun ،m. o.Solam. p. ftellam. q.itidem. r. lupum. s. Norias fiord. i.e.

Figure 13. Drums $C \& D$ from the Latin publication 1673 (microfilm). 


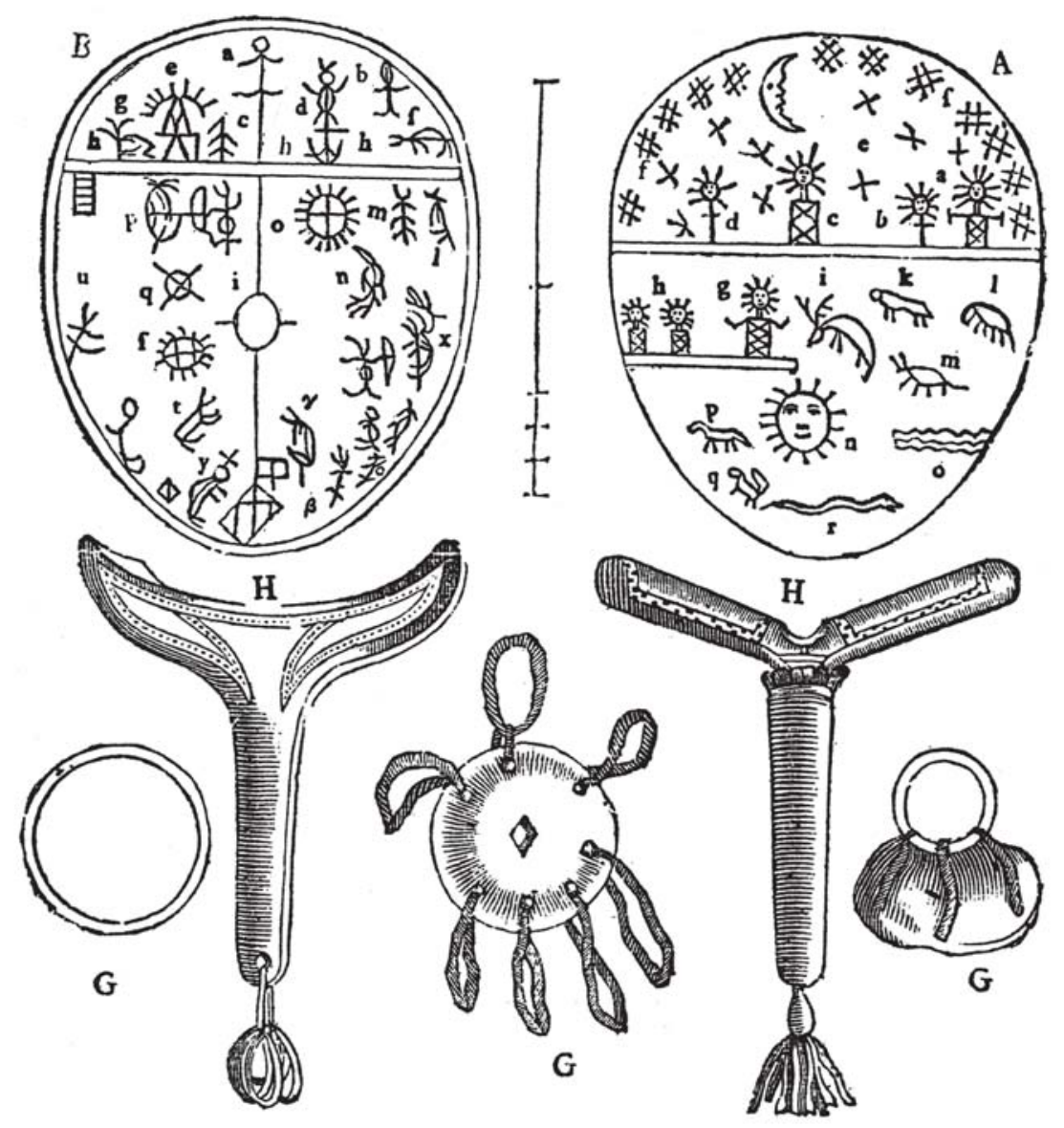

The Explication of the Figures.

In the Drum A. a markes Thor. b Thors Servant. c Storjnnkare. d his Servant. e Birds. f Stars. $\mathrm{g}$ Chrift. $\mathrm{h}$ bis Apoftles. $\mathrm{i}$ a Bear. $\mathrm{k}$ a Wolf. $\mathrm{I}$ a Rain-deer. $\mathrm{m}$ an Ox. $\mathrm{n}$ the Sun. o a Lake. p a Fox. q a Squeril. $\mathrm{r}$ a Serpent.

In the Drum B. a denotes God the Father. b Fefus Chrift. c the Holy Ghoft. d S. Fohn. e Death. f a Goat. $g$ a Squeril. h Heaven. i the Sun. 1 a Wolf. $m$ the firs Siik, n a Cock. o Friendjhip with the wild Rainodeer. $\mathrm{p}$ Anundus Eerici (whofe Drum this was) killing a wolf. q Gifts. $\mathrm{r}$ an Otter. $\mathrm{f}$ the friendßip of other Lapps. $\mathrm{t}$ a Swan. u a fign to try the condition of others, and whether a difease be incurable. $\mathrm{x}$ a Bear. Y a Hog. $\beta$ a Fifh. $\gamma$ one carrying a Soul to Hell.

Figure 14. Drums A \& B from the English publication 1674 (photocopies). On analysis of the drums and the positioning of the figures themselves, when contrasted with the Latin drums, most of the figures are reversed. Note that the text describing the figures on the drums is not clear because these are photocopies from the 1971 republication of The History of Lapland. 

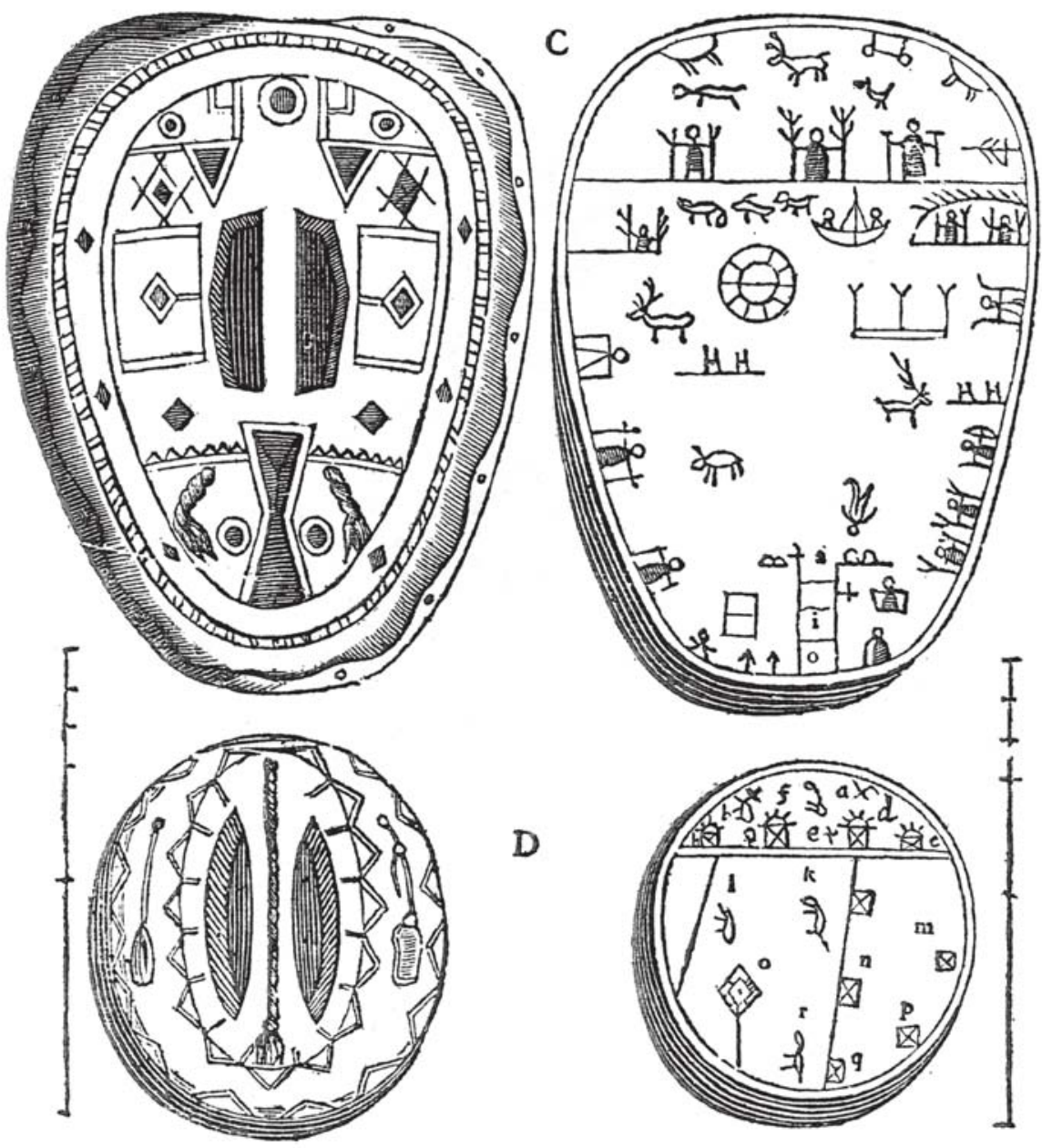

The explication of the Figures.

In the Drum $E$. a denotes Birds. b black Foxes. c T'insr, a God. d Thor, a God. e Thors bammer. f Storjunkare. $g$ a wooden Idol. h his Servant. i a Star. k an Ox. 1 a Goas. m a Siar. $n$ the Moon. O the Sun. $p$ a Star. q axother Star. I a wolf.

Figure 15. Drums $C \& D$ from the English publication 1674 (photocopies). The case is the same with these drums as well, the figures are reversed. 
circular shapes with lines across the middle which look like creatures with many legs, or even a figure representing the Sun?

Drum B is also located in the book, in the chapter about not existing drums, Nicht erhaltene Trommeln.

In a similar fashion to drums A \& B, drums C \& D are also divided into zones with the names of the figures documented below in Latin. The significant characteristics on the face of drum $\mathrm{C}$ show in the top zone three Divine like figures, and above them animals facing right to the east. Below the top zone is a large area and in the left hand corner at the top, there are two figures, holding poles/sticks, who are in a kind of enclave. Just to the right of the centre, is a Sun motif. The divided areas on drum D show four different zones. The figures in the top part are not easy to identify clearly. However, what is important to recognise here are the motifs in the zones to the left and centre of the drum. The left side has square box-like structures which are marked by a cross from corner to corner, and the zone in the centre of the drum shows three animal figures facing right to east. Drum C, pictured in all Schefferus's publications is recorded by Manker as "probably being from Lule Lappmark" (1938: 788). The drum was on display in the National Historical Museum, Stockholm. Drum D, from the Schefferus publications is also pictured in Manker's inventory.

These magical drums appear to have been drawn by hand and then examined in detail, giving a descriptive account of animal figures such as reindeer as well as solar and lunar symbols which are apparent on the drum surfaces. The presence of deities is also evident on the drum. According to the analysis of the drum figures here, the figures of Thor's servant and what are referred to as Apostles are seen on the same drum, indicating the contrast between Paganism and Christianity amongst the Sami the time the drums were collected around 1670, and this is important to acknowledge as it shows both the cultural and religious change at the time.

Firstly, the argument presented here is used to clarify the extent of the different errors found in Lapponia, and to state the obvious, that Schefferus is not at fault with reference to the variations of these drum illustrations pictured reversed in the early publications. Secondly, the aim is to consider these implications caused by the presentation of this material which reached a global audience during the seventeenth century. It may be added that the use of this material still continues to some extent in the countries aforementioned, to the present date and these mistakes are not necessarily obvious. It is also worth mentioning that both the United Kingdom and France have drums in their museum collections which are on exhibit there. Therefore, these pictorial mistakes have both historical and cultural implications for scholars as far 
as the use of these sources as primary source material goes when analysing the structure and content of the drums for religious purposes and understanding Sami culture.

A further point in need of clarification is that these original copies are all very highly priced and valued from what I have been able to determine because of their age, without any awareness of these errors.

As scientists in the field of religious, ethnographical and cultural research, the challenge of interpreting the drums and the literature associated with them in relation to the study of comparative religion has been clearly outlined by scholars such as T. I. Itkonen (1943-1944), Ernst Manker (1938, 1950), Håkan Rydving (1993), Tore Ahlbäck \& Jan Bergman (1991), and Rolf Kjellström (1991), all of whom through both field work and in depth textual analysis of the early material published in relation to the religion of the Sami and their culture, stress not only to the complexity which surrounds the specific usage of the drums for a wide variety of ceremonial and cultural activities, but more problematically the context through which interpretation of painted illustrations ranging from humans, animals, gods, goddesses, human and animal like figures in different zones actually takes place outside of Sami culture by scholars.

The challenge of understanding the drum illustrations with reference to certain symbols carefully selected and painted in the areas within the zones and representing for example places such as mountains, and holy offering places, known in the physical environment, presents further difficulty because some of the drums were painted both for individual usage as well as collective. Furthermore, they were illustrated in a religious sense as well in relation to culture and cosmology, but at the time they were collected by the priests, the drums were in some cases subject to interpretation by the priests themselves rather than those who had made them.

The current understanding of the division between different areas on the surface of a drum is that they represent physical and psychic realities or spiritual worlds, namely the top level where certain deities reside as the "celestial sphere of the drum" (Pentikäinen 1998: 26), the middle zone as representing the physical world, and the lower part of the drum in most cases is a representation of the area where the dead reside.

Previous material produced by Manker, Kjellström and Itkonen has, for example, discussed the complexities surrounding the interpretation of the variation of the painted figures on the drums constructed before conversion to Christianity took precedence, during the time when the Sami were in the process of being converted to Christianity, and after conversion to Christianity in certain areas had taken place. By the fact that many of the symbols on drums constructed at different times are mixed with both Christian and Sami 
symbols and representations, the task of interpretation is difficult in relation to understanding these "psychic landscapes" which were in a gradual process of change.

In addition to this, the early Sami cosmology or world-view shows animatistic, animistic and totemic features. "Nature was regarded as animated; meaning each important feature, mountain, hill lake, waterfall, grazing area etc., had its own local deity. The powers of nature, sun, thunder, wind, frost etc., were personified in god-figures, sickness and death in evil spirits of demons." (Whitaker 1957: 296) This point in itself creates misunderstanding because in a modern sense the scientific world-view deals with concrete everyday physical reality. Also, it would be true to say that many of these personifications of spirits and deities would have varied considerably in each area.

Totemism on the other hand, in the Sami pre-Christian society was a "concept according to which social groups such as extended families or clans have close relationships with particular animals" (Pulkkinen et al. 2005: 417). Totemism is here understood in a modern way as broad concept and not presupposing particularly a fore father relationship. There are many examples of the ties between the Sami and animals, such as the bear and reindeer which are featured on many of the divination drums. The positioning of these figures is known to have been of crucial importance for the Sami using the drums to bring balance and alignment in the relationship between human beings and the natural environment, for example, in relation to hunting which is one of the central features in shamanism.

Seen depicted in its true context on drum F from Kemi Lappmark, on the right hand side in the top corner of the middle zone, is the illustration of a bear in its den sleeping, therefore, we can assume this is during the winter months.

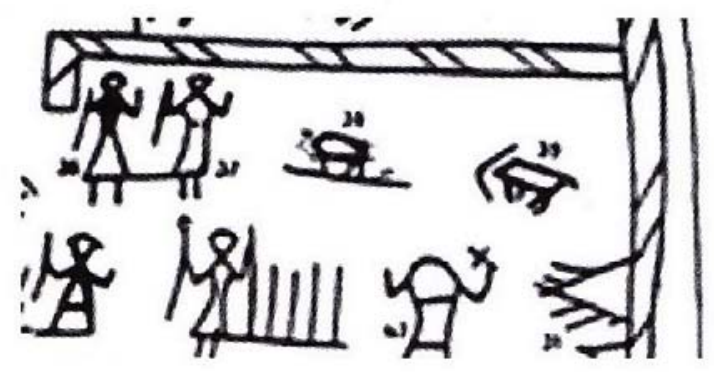

Figure 16. This illustration is taken from the 2005 publication: The Saami: A Cultural Encyclopedia, page 33. It shows one of the rare images of a bear in its winter hibernation on the Kemi Lappmark drum F, currently on display in Leipzig. In the earlier copies this location is reversed. Here the bear is numbered as image 39 in the right upper row. 
Needless to say, the location of the bear in its den seen in the publications which show the figures reversed, positions the location on the left side. The problem caused by this error needs to be made clear because it is understood the "bear had a special cultic position in Saami culture" (Pulkkinen et al. 2005: 33). In addition, associated with the bear were a number of very specific taboos and certain ritualistic practices adhered to stating the relationship between the bear and human beings, a very old custom well documented in Sami folkloristics with reference to astral mythology and cosmic order, as well as bear hunting ceremonies, and the events which took place both before and after, which included songs about the animal sung in association with the drum images before hunting begun. All of these activities contributed to the maintenance of their livelihoods as hunter people.

\section{THE CONSEQUENCES OF THESE PUBLICATION ERRORS}

The difficulties presented to scholars of the history of religion with regard to analysing and interpreting the information on the surfaces of the drums has been well documented by both Nordic scholars Rolf Kjellström and Bo Sommarström in their analysis of how the information was collected by clergymen, missionary workers and explorers alike. For the most, explanations of the ways in which a drum scene was interpreted in accordance with the positioning of each figure by the noaidi, are not known because the drums were collected at a time when "the drums represented their threatened culture, the resistance against the Christian claim to exclusiveness, and a striving to preserve traditional values" (Rydving 1991), and therefore illustrations without commentary from the artists themselves present a great risk for error of judgement and interpretation by those outside the culture.

It is almost certain the structure and content of many of the drums were both influenced and characterised with reference to hunting by both solar and lunar activity as well as the orientation of the different elements of earth, air, fire and water, and understood within the four cardinal points of north, east, south and west. These factors are in addition to the structure of the Noaidi's cosmos as seen portrayed within the three cosmic levels or zones through which the surface of the drum was divided into.

An early reference clearly stating the importance of this found on page 49 in the first English edition of Lapponia. Schefferus states that:

"I have observed that several of their drums have not the same pictures upon them. They are described differently in which the figures are distinguished so as to refer to several places, of which there are chiefly 
three. In the first stands Norland, and other countries of Sweden which are placed on the South side of the drum, and are represented by a line from the rest, in this also is contained the next great city, where they traffic most, as in drums made at Torne, or Kiemi. On the North part, Norway is described with all that is contained in it. In the middle of these two stands Lapland, this takes up the greatest part of the drum, here they picture herds of reindeer, bears, foxes, wolves and all manner of wild beasts, to signify when, and in what place they may find them." (Schefferus 1674: 49)

The quote by Schefferus is crucial because for example, it shows how important it was for the Sami to know the specific positioning of the figures on the drums with reference to using the instrument for divination to secure a successful outcome prior to hunting when they were travelling, for example, on harsh migration routes during the months between summer and winter. It is also worth noting that in the 1980s the interest amongst scholars, with regard to the Sami noaidi drums belonging to the Scandinavian countries, was as such that, a symposium was held in Turku, Finland on August 19-20, 1988, titled The Saami Shaman Drum. The organising committee - Rolf Kjellström, Håkan Rydving and Tore Ahlbäck - pointed out that:

"there were a number of different ways that the Saami drum might be approached, e.g. an analysis of drum illustrations or individual drums, categorisation by region and/or type of Saami drums, the role of the drum in Saami society and religion, the significance of drum music from the shaman's ritual ecstasy, drum illustrations as a source of information on the Saami world-view." (Ahlbäck \& Bergman 1991: 7)

The material presented at the symposium was published in the book titled The Saami Shaman Drum.

I want to outline in particular here the conclusions of one of the contributors, namely Rolf Kjellström, who focuses on the importance of the positioning of figures on the drum $\mathrm{F}$ from the Kemi Lappmark area. Kjellström refers to a group of three animals in his presentation, two of which can be identified as reindeer because of their antlers and are illustrated in the top zone on drum F. He makes it clear that when analysing reindeer which are the most commonly occurring figures on the drums "often the reindeer figures stand alone on one of the three upper rays of the sun figure, or on the left-hand edge of the drum but rarely on the right-hand side, or floating freely in the middle of the picture surface" (Kjellström 1991: 117). At the end of the chapter Kjellström lists a small chapter regarding the "different ways of classifying drums with refer- 
ence to images and positioning of drum illustrations (which includes) the connection between figures and positions in relation to signs on the drum" (Kjellström 1991: 133).

What this evidence does show that the publication errors of the drum illustrations that have been formulated and then presented in the first and second editions of the English editions, as well as the French and Dutch ones by the publishers, and although unintentional, these mistakes complicate the opportunity for further understanding or insight into the content of each of the scenes on the drum. Instead, this takes us away from understanding these expressions of Sami nature religion and culture at a time of religious change, and therefore, for a number of reasons this makes the material misleading not only to scholars, contributors to the history of religion, but to the Sami themselves.

Due to the extent of these errors, there is a need for the mistakes in the material to be brought to the attention of the institutions, museums and establishments where copies of Lapponia are held, because for example, and more importantly, should scholars from the aforementioned countries of France, Great Britain and Holland, or any other country for that matter, use these drum illustrations which are reversed from the original copies for producing material ${ }^{14}$, but perceived as true illustrations without any knowledge of the errors, then these mistakes will keep on repeating themselves.

\section{CONCLUSION}

How do these mistakes affect the ritual practices and also the world-view of Sami culture and religion? The task of the scholar of comparative religion is to study and analyse the differences and similarities between religious rituals, concepts, and different approaches taken to ascertain the reliability of source material of religious phenomena. In this case, the analysis has been between different editions of the same source material published at different times in different languages, in different countries.

The importance of the positioning of zones and figures on the drums has been essential for the Sami community for understanding how the landscape, of both the physical and mythological worlds, was ritualised and then portrayed in association with how the function of the cosmos was interpreted and understood within their culture which formed a sense of unity amongst the people. This understanding was then expressed in a holistic way within Sami religion as an expression of maintaining a state of cosmic order between the different levels of existence, especially the realm of nature. 
It was understood that what took place on the earth was reflected in the skies and in the world of the ancestors, thus highlighting the relationship between the supernatural world, where certain deities or totemic ancestral spirits resided, and the physical world and how, for example, the animals in the physical reality were related to those in the spiritual realities.

Both the content and layout and positioning of figures that have been painted onto the surfaces of the drums, such as animals, humans and deities who have played a central role in the Sami world-view, hunting and community, have historical value within Sami culture because the drums have been pictographs used for recording different chapters throughout history in Lapland. A good example of this from both a religious and historical point of view would be the historical differences portrayed on the drums depicting "the religion during the hunting stage and the religion of the nomadic stage" (Hultkrantz 1983: 11) showing when and where reindeer had become domesticated. Another example would be the appearance of Christian symbolism such as crosses and the positioning of churches in certain villages or towns, which were previously unknown on the earlier drums.

More recently, a further hypothesis has been put forward, suggesting that the content, positioning and layout of animal figures on some Sami drums correspond with certain "star horizons" (Sommarström 1991:136) in the sky, which represents the theory of totemism. If this is the case, then the differences seen on the drums which are presented here, change the understanding of both the relevance of the figures in their positions in the sky and their geographical locations of the mythological world, as well as the hunting areas on the tundra. We know that because of seasonal variation when the Sami migrated between different locations on migratory routes for hunting and fishing, a way of recording these locations, which included rivers, mountains and caves (where bears were sleeping), was on the surfaces of the drums, which is why they are sometimes referred to as maps.

The aim of this article has been to clarify the importance of the survey of the Sami noaidi drums and this undertaking has established a number of errors relating to the way in which the material has been published in France, Holland and the United Kingdom with reference to historical data and Sami culture and religion. Therefore, it can be stated these illustrations in the English, Dutch and French editions cannot be relied upon as any kind of authenticity, because the illustrations have a number of important features which are portrayed as mistakes due to the ways in which the editions have been printed. Although these mistakes do not necessarily make the editions invalid, however, the reliability of these sources as material which represents the knowledge of the noaidi as seen portrayed through the intricate symbolism illus- 
trated in detail on the drums, and also the position of the drums as cultural and historical artefacts and representations of Sami religion and culture, need to be made clear due to these historical inaccuracies which misrepresent the Sami, Sami culture and religion.

\section{ACKNOWLEDGEMENTS}

I would like to express my sincere thanks to the following people for their help and assistance in writing this article. Professor Elina Helander-Renvall from the Arctic Centre, Rovaniemi. Docent Risto Pulkkinen from the University of Helsinki Department of World Cultures. Tim Pye from the Rare Books Reference Service at the British Library. Kristiina Nayho at Finnish Literature Society, Helsinki. Pascal Cotroux for the translation from French to English and Sirkka Havu from the National Library of Finland.

\section{NOTES}

1 The term shaman today is generally not applicable in Lapland amongst the Sami; its origins can be found in the early Russian sources. In Lapland the traditional healer has been compared to a Medicine Man or Woman known as Noaidi.

2 A further point for the reader's attention is the usage of the terms: 'Lapp', 'Sami' and 'Saami' throughout the article. The terms 'Lapp' and 'Lappish' have been used extensively and particularly in early literature mainly by outsiders and is considered derogatory by the Sami. The application of the term in this article is used only in quotes from literature. The term 'Sami' is the Finnish word used when referring to the native people of northern Scandinavia, as is the Swedish word Saami. Both of these are also used in quotes from English and Swedish literature in this article. Furthermore, both of these are used today to help distinguish the native people of Lapland from those who live there but whose roots maybe elsewhere.

3 The museum is nowadays called Museum für Völkerkunde zu Leipzig (Leipzig Museum of Ethnography) and it is a part of the Grassi Museum.

4 The word noaidi is used here as a technical term to point out to all the drum users. According to Risto Pulkkinen, at least on the more southern parts of Sápmi the drum was not the privilege of the noaidi only but the use of the drum (in divining ) was each person's right.

"Recalling Ancestral Voices is a project dedicated to recording the material cultural heritage of the Sámi. The project was launched in April 2006 and ended in November 2007. In Finland, the Sámi Museum Siida is participating in the project, in Sweden, the Ájtte Museum in Sweden and Varanger Sámi Museum in Norway." (This quote is from the web site address below). The discussion about the Sami noaidi drums can be viewed in a wider scientific context with reference to previous 
research, seminars and discussions about drums, as well as a number of other indigenous artefacts in relation to Sami cultural history. The information about the project is in Swedish, Finnish and Sami language. http://www.siida.fi/heritage/english/index.html

5 The list of manuscripts that were received at different times by Schefferus, and contain in particular the writings of Rheen and Tunderus, as well as information from other priests of the northern areas, can be found in the National Library also under the title Lapponia, which is as a compilation of sources given to Schefferus.

${ }^{6}$ For information about the manuscripts concerned with bear hunting rituals made by Gabriel Tunderus, see Fragments of Lappish Mythology, edited by Juha Pentikäinen, English translation (Laestadius 1997).

${ }^{7}$ See the foreword at the beginning of the book.

8 On-line research into the current sale prices of the 1674 English edition and the French and Dutch editions at a Antiquarian book sellers revealed the cost for the original copies are as follows: English 1674 edition on sale in Stockholm, Sweden: 2,420 euros, French edition on sale in the United States, California: 801.00 euros, and the Dutch edition is on sale in the Netherlands: $1,250.00$ euros.

9 According to the British Library catalogue, there are copies of The History of Lapland on microfilm and in digital form, distributed to a number of institutions in different parts of the world. I contacted Tim Pye from the Rare Books Reference Service at The British Library and he supplied me with the following information. One of the most comprehensive and reliable sources for identifying the various editions of a particular work is the English Short Title Catalogue (http://estc.bl.uk) (the catalogue also indicates which institutions around the world hold copies of a work). The ESTC lists four distinct English editions of The history of Lapland - two published "at the Theater in Oxford" in 1674 (ESTC nos. R8773 \& R183263), one printed in London "for Tho. Newborough" in 1704 (T146952), and one printed in London "for R. Griffith" in 1751 (T111934). The catalogue records for the 1674 editions attribute the translation into English to Anton Cremer. The Library's 1704 and 1751 editions have been digitised and are available via Eighteenth Century Collections Online, a subscription database that is available in many libraries and universities. One of the 1674 editions has also been digitised and is provided by the Early English Books Online database, but the digitised images are taken from copies held not by the British Library but by the Huntington and University of Illinois Libraries, both located in the United States.

10 Translated from German to English by Kristiina Nayho at Finnish Literature Society.

11 The University of Helsinki does not have the first English publication on microfilm and therefore, I have used photocopied pictures in this case.

${ }^{12}$ Comparison of some illustrations with their sources and derivations. Lillemor Lundström has created an on-line version of the 1674 English edition of The History of Lapland, and addresses the issue or reversed images by correcting them for this version of the original English text. He states the following: "The illustrations in the 1674 English translation of the book are imitations of those in the Latin source text from 1673. Apart from being mirror-images of the originals, some noteworthy changes were made; a few of these are commented below. As in the main text, I have here 
reversed the English illustrations back to their intended orientation, and then individually reversed all letters in the legends, as well as colouring these and any scale bars red. Chapter X contains two illustrations, both depicting the worship of idols. In the original, the idols' heads are crudely shaped as described in the text, while their English counterparts have been changed to have clearly visible facial features, contrary to the description." Sourced from: http://old.no/samidrum/lapponia/ this is the web address where the corrected pictures of the two Finnish drums from Kemi Lappmark can be viewed in the chapter Of the magicall Ceremonies of the Laplanders: http://old.no/samidrum/lapponia/chap-xi.html

13 The translation from the old French text to English which can be found in the introduction in the book was made by the grateful assistance of Pascal Cotroux.

${ }^{14}$ On a visit to the National Library of Finland in Helsinki, the cost for a photocopy of the illustration of the drums from the First English Edition was ten euros and no one there had any knowledge concerning the errors.

\section{REFERENCES}

Ahlbäck, Tore \& Bergman, Jan (eds.) 1991. The Saami Shaman Drum; Based on Papers read at the Symposium on the Saami Shaman Drum held at Abo, Finland, on the 18th-20th of August 1988. Åbo: The Donner Institute for Research in Religion and Cultural History.

Ahlström, Gunner 1971. The History of Lapland, wherein are shewed the original, manners, habits \&c. of that people. Suecica rediviva 22. Facsimile ed. Stockholm: Bokforlaget Rediviva.

Hultkrantz, Ake1983. Reindeer nomadism and the Religion of the Saamis. In: B. R. Jonsson (ed.) ARV Scandinavian Yearbook of Folklore 39. Stockholm: The Royal Gustavus Adolphus Academy.

Itkonen, Toivo Immanuel 1943-1944. Suomen Lappalaisten Muinaisuskosta. [The Old Religion of the Lapps in Finland.] Kalevalaseuran Vuosikirja 23-24. PorvooHelsinki: Werner Söderström Osakeyhtiö.

Kjellström, Rolf 1991. Traditional Saami Hunting in relation to drum motifs of animals and hunting. In: T. Ahlbäck \& J. Bergman (eds.) The Saami Shaman Drum; Based on Papers read at the Symposium on the Saami Shaman Drum held at Abo, Finland, on the 18th-20th of August 1988. Åbo: The Donner Institute for Research in Religion and Cultural History.

Laestadius, Lars Levi 1997. Fragments of Lappish Mythology. Edited by J. Pentikäinen; with an introduction and an afterword by Juha Pentikäinen. Beaverton: Aspia Books.

Lundström, Lillemor 2002.SCHEFFERUS Johannes (1621-1679). http://www.royallibrary.se/ F1700/Lapland/Lapland.htm, last accessed on 30 March 2011.

Lundström, Lillemor 2009. The History of Lapland: Comparison of some illustrations with their sources and derivations. http://old.no/samidrum/lapponia/illustrations.html, last accessed on 30 March 2011. 
Manker, Ernst Mauritz 1938. Die lappische Zaubertrommel. Eine ethnologische Monographie 1, Die Trommel als Denkmal materieller Kultur. Acta Lapponica 1. Stockholm: Thule.

Manker, Ernst Mauritz 1950. Die lappische Zaubertrommel. Eine ethnologische Monographie 2, Die Trommel als Urkunde geistigen Lebens. Acta Lapponica 6. Stockholm: Gebers.

Pentikäinen, Juha 1998. Shamanism and Culture. 3rd rev. ed. Helsinki: Etnika.

Pulkkinen, Risto \& Kulonen, Ulla-Maija \& Seurujärvi-Kari, Irja 2005. The Saami. A Cultural Encyclopaedia. Helsinki: The Finnish Literary Society (SKS Kirjat).

Rydving, Håkan 1993. The End of Drum-Time: Religious Change among the Lule Saami 1670s-1740s. Historia religionum 12. Uppsala: Almqvist \& Wiksell International.

Rydving, Håkan 1991. The Saami Drums and the Religious Encounter in the 17th and 18th Centuries. In: The Saami Shaman Drum; Based on Papers read at the Symposium on the Saami Shaman Drum held at Abo, Finland, on the 18th-20th of August 1988. Åbo: The Donner Institute for Research in Religion and Cultural History.

Schefferus, Johannes 1673. Joannis Schefferi Argentoratensis Lapponia. (Latin edition). Frankfurt am Main und Leipzig: Martin Wallerborden/Buchhåndlern.

Schefferus, Johannes $1674=$ The History of Lapland, wherein are shewed the original, manners, habits \&c. of that people. 1971. Suecica rediviva 22. Facsimile ed. Stockholm: Bokforlaget Rediviva.

Schefferus, Johannes 1678. Histoire de la Laponie. Paris: chez la veuve Olivier de Varennes.

Schefferus, Johannes 1682. Waarachtige en aen-merkens-waardige Historie van Lapland. Amsterdam: Jan ten Hoorn.

Schefferus, Johannes 1704. The History of Lapland. London: Printed for Tho. Newborough.

Schefferus, Johannes 1956. Lapponia. Acta Lapponica 8. In: E. Manker et al. (ed). Uppsala: Almqvist \& Wiksell.

Schefferus, Johannes 1963. [Lapponia] Lapponia eli Lapin maan ja kansan uusi ja todenmukainen kuvaus, jossa esitetään paljon tähän asti tuntemattomia tietoja lappalaisten alkuperästä, taikauskosta ja-menoista, ravinnosta, elintavoista ja askareista, samoin eläimistä ja eri metalleista, joita on heidän maassaan, huolellisesti kuvitettuna valaisevilla piirroksilla. Transl. from Latin by T. Itkonen. Acta Lapponica Fenniae 2. Kariston klassillinen kirjasto 70. Hämeenlinna: Karisto.

Sommarström, Bo 1991. The Saami Shaman's Drum and the Star Horizons. In: T. Ahlbäck \& J. Bergman (eds.) The Saami Shaman Drum; Based on Papers read at the Symposium on the Saami Shaman Drum held at Abo, Finland, on the 18th-20th of August 1988. Åbo: The Donner Institute for Research in Religion and Cultural History.

Whitaker, Ian 1957. The Holy places of the Lapps (English summary). In: E. Manker Lapparnas heliga ställen: kultplatser och offerkult i belysning av Nordiska museets och landsantikvariernas fätundersökningar. Acta Lapponica 13. Stockholm: Geber. 